\title{
Postmarketing surveillance of the safety of cimetidine: 12 month mortality report
}

\author{
D G COLIN-JONES, M J S LANGMAN, D H LAWSON, M P VESSEY
}

\begin{abstract}
A total of 9928 patients taking cimetidine and 9351 controls were recruited to a postmarketing drug surveillance study in Glasgow, Nottingham, Oxford, and Portsmouth. Takers were identified by the Prescription Pricing Bureau at Nottingham and by dispensing pharmacists at the other three centres. All but $1.2 \%$ of the takers and $1.6 \%$ of the controls were successfully followed up for one year during which hospital visits and deaths were recorded. Three hundred and seventy five of the cimetidine takers and $\mathbf{1 9 8}$ of the controls are known to have died. Most of the difference in mortality was accounted for by an excess among the takers of deaths from cancers of the oesophagus, stomach, colon, and lung; from neoplasms of the lymphatic and haematopoietic system; and from ischaemic heart disease, chronic liver disease, and accidents and poisonings. So far as can be assessed, however, none of these drug-
\end{abstract}

Queen Alexandra Hospital, Cosham, Portsmouth D G COLIN-JONES, MD, FRCP, consultant physician

Department of Therapeutics, City Hospital, Nottingham M J S LANGMAN, MD, FRCP, professor

Department of Clinical Pharmacology, Royal Infirmary, Glasgow D H LAWSON, MD, FRCPED, professor

Department of Community Medicine and General Practice, Radcliffe Infirmary, Oxford

$M$ P VESSEY, MD, FRCPED, professor

Correspondence to: Professor M P Vessey. disease associations represented adverse effects of cimetidine treatment; on the contrary, they resulted from cimetidine being used, knowingly or unknowingly, for treating the symptoms of various diseases or for alleviating adverse effects of other agents such as corticosteroids, non-steroidal anti-inflammatory drugs, and radiotherapy. No evidence of any fatal adverse effects of cimetidine emerged in this study.

\section{Introduction}

Cimetidine (Tagamet) was first marketed in late 1976 for the treatment of gastric acid related disease and soon became widely used (about 25 million patients have now taken the drug worldwide). As a new pharmacological entity, which could have effects on many body systems, ${ }^{1}$ cimetidine was clearly an eminently suitable drug for an experimental postmarketing surveillance study. Accordingly, in 1977 we investigated the possibility of identifying about 10000 takers of cimetidine (and a similar number of controls) in four centres (Glasgow, Nottingham, Oxford, and Portsmouth) with a view to monitoring hospital visits and deaths among them over at least 12 months. The study proved feasible and we have already outlined the methods used ${ }^{2}$ and reported our findings on gastric cancer. ${ }^{3}$ We now describe the survey methods in more detail and present an analysis of the deaths occurring in patients taking cimetidine and in the controls during the initial 12 month follow up period.

\section{Methods}

Approval of the study was obtained from the Pharmaceutical Society of Great Britain, the Committee on Safety of Medicines, local medical committees, hospital medical staff committees, and individual pharmacists and general practitioners. 
IDENTIFICATION OF TAKERS

In Nottingham cimetidine takers were identified by copies of prescriptions supplied by the Prescription Pricing Bureau. At the other three centres the names and addresses of takers and doctors, together with prescription details, were obtained on a form from the dispensing pharmacists, who were paid a small honorarium. Pharmacists were given a list of participating doctors to ensure that unauthorised information was not disclosed, although acceptance of the study by general practitioners (and pharmacists) was excellent. In all, 327 practices and 254 pharmacies took part.

The identification of cimetidine takers began in Nottingham in January 1978 and in the other three centres in the summer of the same year. Once sufficient notifications had been received to make a visit to a particular practice worth while, an experienced research assistant identified the practice medical records for each taker and recorded the taker's full name and address, date of birth, and National Health Service number, together with the date cimetidine treatment was first started (often months before the date of the first notification), the total number of tablets prescribed (if known), and the indication for treatment. All notified takers were included in the study except for temporary visitors. The delay between notification of a taker and the visit to the practice was rarely longer than three months. Nevertheless, some takers had died before the practice could be visited, but these subjects were still included, the date of entry to the study for takers being the date on the first notified prescription.

\section{SELECTION OF CONTROLS}

At the same practice visit a control was selected for each taker by identifying the medical record nearest to the taker's relating to a subject $(a)$ of the same sex, $(b)$ whose age was in the same decade, $(c)$, who had been seen at the practice in the previous 12 months, and $(d)$ who was not known to have received cimetidine. The entry date to the study for each control was taken as the date of the practice visit, so the 12 month follow up periods for takers and their corresponding controls were slightly (usually three months or less) out of phase. Because of local circumstances in Glasgow a control was not selected for every taker.

\section{REVIEW OF PATIENTS' RECORDS}

The general practitioner's records for each taker and control were examined again after about 15 months, which provided sufficient time for discharge summaries, hospital letters, etc, relating to the 12 month survey period, to have reached the practice. At this practice visit the dates of all outpatient attendances and hospital admissions, together with the diagnoses made, were noted. An attempt was made to estimate whether each disorder had started before or after the patient entered the study. In addition, prescription details were verified, any event considered by the general practitioner to have been an adverse reaction leading to the withdrawal of cimetidine was noted, and deaths were identified. Subsequently, copies of death certificates and necropsy reports were obtained. Illnesses and causes of death were coded according to the ninth revision of the International Classification of Diseases. ${ }^{4}$ Patients who had left the practice were, when possible, traced with the help of the family practitioner committee and information sought from the new general practitioner either at a visit or by a postal questionnaire.

\section{QUESTIONNAIRE ON SMOKING}

During the preliminary analysis of the data we noticed that deaths from diseases related to smoking were commoner among takers than controls. Accordingly, with the consent of the practices concerned, a postal questionnaire was sent to a sample of takers and controls, selected at random and known to be alive, in each of the four centres to try to discover whether or not smoking habits differed between the two groups. Questions on consumption of alcohol, tea, and coffee and about stress were also included.

\section{RECORDING AND ANALYSIS OF DATA}

All data were recorded on pressure sensitive paper, but the copies of the forms sent for computer processing did not include any informa- tion about patients' names, practices, or hospitals. Analyses were carried out, under our direction, in the computing division of Smith Kline \& French Laboratories.

\section{Subjects}

A total of 9928 takers entered the study: 2552 at Glasgow, 2069 at Nottingham, 2654 at Oxford, and 2653 at Portsmouth. The overall number of controls (9351) was smaller than that of takers largely because of local difficulties in recruitment at Glasgow. Subjects lost to follow up during the survey year amounted to $1.2 \%$ of the takers (varying from $0.6 \%$ to $2.0 \%$ at the different centres) and $1.6 \%$ of the controls (varying from $0.6 \%$ to $2.6 \%$ at the different centres). In addition, 64 controls who started taking cimetidine during the survey year were excluded from further analysis.

Of the subjects followed up for 12 months, $63 \%$ of the takers were men; male takers tended to be younger than female takers. Within the centres the proportion of male takers varied from $58 \%$ (Portsmouth) to $66 \%$ (Oxford). The mean ages of the takers in Glasgow (men 47 women 53) were lower than the mean ages of those in the othe centres (Nottingham, men 51, women 57; Oxford, men 55, women 57; Portsmouth, men 53, women 58).

\section{Results}

\section{MORTALITY RATES}

Table I compares the observed mortality during the 12 month follow up period in each centre with the mortality expected on the basis of national rates. Overall, the ratio of observed to expected deaths was 1.8 for the takers and 1.0 for the controls. A considerable variation was found in the mortality ratios from centre to centre-with Glasgow at the lower end of the range and Portsmouth at the upper end-both for takers and controls (table I). This variation presumably reflects differences in the populations sampled at the various centres.

TABLE I-Observed and expected* numbers of deaths from all causes during the 12 month follow up period for each centre by sex

\begin{tabular}{|c|c|c|c|c|c|c|}
\hline \multirow[b]{2}{*}{ Deaths } & \multicolumn{3}{|c|}{ Takers } & \multicolumn{3}{|c|}{ Controls } \\
\hline & $M$ & $\mathrm{~F}$ & Total & $\mathbf{M}$ & $\mathrm{F}$ & Total \\
\hline $\begin{array}{l}\text { Glasgow: } \\
\text { Observed } \\
\text { Expected } \\
\text { Ratio } \\
\text { Rotingham. }\end{array}$ & $\begin{array}{l}36 \\
26 \cdot 7 \\
1 \cdot 3\end{array}$ & $\begin{array}{l}18 \\
15 \cdot 9 \\
1 \cdot 1\end{array}$ & $\begin{array}{l}54 \\
42 \cdot 6 \\
1 \cdot 3\end{array}$ & $\begin{array}{l}13 \\
20 \cdot 4 \\
0 \cdot 6\end{array}$ & $\begin{array}{l}8 \\
13 \cdot 2 \\
0 \cdot 6\end{array}$ & $\begin{array}{l}21 \\
33.6 \\
0.6\end{array}$ \\
\hline $\begin{array}{l}\text { Nottingham: } \\
\text { Observed } \\
\text { Expected } \\
\text { Ratio } \\
\text { Oxford: }\end{array}$ & $\begin{array}{l}42 \\
26 \cdot 0 \\
1 \cdot 6\end{array}$ & $\begin{array}{l}20 \\
14 \cdot 7 \\
1 \cdot 4\end{array}$ & $\begin{array}{l}62 \\
40 \cdot 7 \\
1 \cdot 5\end{array}$ & $\begin{array}{l}27 \\
24 \cdot 7 \\
1 \cdot 1\end{array}$ & $\begin{array}{l}10 \\
12 \cdot 7 \\
0 \cdot 8\end{array}$ & $\begin{array}{l}37 \\
37 \cdot 4 \\
1 \cdot 0\end{array}$ \\
\hline $\begin{array}{l}\text { Observed } \\
\text { Expected } \\
\text { Ratio } \\
\text { Portsmouth: }\end{array}$ & $\begin{array}{l}86 \\
39 \cdot 8 \\
2 \cdot 2\end{array}$ & $\begin{array}{l}37 \\
22 \cdot 0 \\
1 \cdot 7\end{array}$ & $\begin{array}{l}123 \\
61 \cdot 8 \\
2 \cdot 0\end{array}$ & $\begin{array}{l}37 \\
37 \cdot 8 \\
1 \cdot 0\end{array}$ & $\begin{array}{l}29 \\
20 \cdot 2 \\
1 \cdot 4\end{array}$ & $\begin{array}{l}66 \\
58 \cdot 0 \\
1 \cdot 1\end{array}$ \\
\hline $\begin{array}{l}\text { Observed } \\
\text { Expected } \\
\text { Ratio }\end{array}$ & $\begin{array}{l}82 \\
36 \cdot 5 \\
2 \cdot 2\end{array}$ & $\begin{array}{l}54 \\
26 \cdot 9 \\
2 \cdot 0\end{array}$ & $\begin{array}{l}136 \\
63 \cdot 4 \\
2 \cdot 1\end{array}$ & $\begin{array}{l}45 \\
34 \cdot 4 \\
1 \cdot 3\end{array}$ & $\begin{array}{l}29 \\
25 \cdot 8 \\
1 \cdot 1\end{array}$ & $\begin{array}{l}74 \\
60 \cdot 2 \\
1 \cdot 2\end{array}$ \\
\hline $\begin{array}{l}\text { Total } \\
\text { Observed } \\
\text { Expected } \\
\text { Ratio }\end{array}$ & $\begin{array}{l}246 \\
129.0 \\
1.9\end{array}$ & $\begin{array}{c}129 \\
79.5 \\
1.6\end{array}$ & $\begin{array}{l}375 \\
208 \cdot 5 \\
1 \cdot 8\end{array}$ & $\begin{array}{c}122 \\
117 \cdot 3 \\
1.0\end{array}$ & $\begin{array}{l}76 \\
71 \cdot 9 \\
1 \cdot 1\end{array}$ & $\begin{array}{c}198 \\
189 \cdot 2 \\
1 \cdot 0\end{array}$ \\
\hline
\end{tabular}

* Expected numbers calculated from mortality tables for England and Wales for the year 1979 for Nottingham, Oxford, and Portsmouth and from mortality tables for Scotland for the year 1979 for Glasgow. Computations based on five year age groupings for England and Wales and 10 year groupings for Scotland.

In table II the deaths occurring among takers and controls are classified by underlying cause. There were several major differences between the two study groups. To assess their meaning we examined in detail all the available documentation about the individuals who died from the diseases showing the biggest variation.

Carcinoma of the oesophagus (ICD 150) (expected mortality in takers at national rates 0.9 men, 0.4 women)-Six of the seven takers had had cancer diagnosed within two months of first taking cimetidine. The drug could not, therefore, have been responsible for the disease in these individuals but instead must have been given for symptoms caused by an undiagnosed cancer. The remaining patient, a 68 year old man with a 15 year history of gastric ulcer, hiatus hernia, and oesophagitis had a benign oesophageal stricture dilated, started taking cimetidine, and did not present for further investigation until 
eight months later when an invasive adenocarcinoma was diagnosed. He had taken an estimated 900 tablets of cimetidine before diagnosis.

Carcinoma of the stomach (ICD 151) (expected mortality in takers 2.9 men, 1.3 women)-Fourteen takers had the disease at or before the date of the first prescription, while another 26 were diagnosed (or died) within six months ( 25 within four months) of first receiving the drug. The remaining five takers were diagnosed (or died) $7,10,12,15$, and 24 months after the date of their first prescription. The relation between cimetidine and gastric cancer in our study is analysed in more detail in another paper $^{3}$ (in which cases of gastric cancer diagnosed outside the survey year are also reported).

Carcinoma of the colon (ICD 153) (expected mortality in takers 1.9 men, 1.6 women - -Six takers had the disease before or at the time of the first prescription, while a further two were diagnosed within two months of starting to take the drug. One taker received about 950 tablets before diagnosis, 19 months after the first prescription, while another received about 1500 tablets over 26 months before the disease was diagnosed.

Carcinoma of the trachea, bronchus, and lung (ICD 162) (expected mortality in takers $12 \cdot 3$ men, $2 \cdot 2$ women)-Seventeen takers were known to have cancer of the lower respiratory tract before starting to take cimetidine, while a further seven were diagnosed within six months of first receiving the drug. The remaining 11 takers with cancer of the lung were first diagnosed more than six months after taking cimetidine (see table III).

Malignant neoplasms of lymphatic and haematopoietic systems (ICD 200-208) (expected mortality in takers 1.6 men, 0.9 women)-The causes of death for the 15 takers were recorded as: malignant lymphoma, six; Hodgkin's disease, one; multiple myeloma, three; lymphosarcoma, three; plasma cell leukaemia, one; lymphoid leukaemia, one. Thirteen of these takers were known to have had their disease before starting to take cimetidine, the drug being prescribed to alleviate symptoms of the disorder or of its treatment (especially with corticosteroids). Of the remaining two takers, one was suspected of having a lymphoma of the stomach at the time cimetidine was first prescribed (the diagnosis being confirmed five months later), while the second was diagnosed at laparotomy 12 months after the first prescription and died three weeks after surgery.

Ischaemic heart disease (ICD 410-414) (expected mortality in takers 41.4 men, 18.4 women)-The difference in mortality from ischaemic heart disease between the takers and the controls (rates in the groups 8.0 per 1000 and 6.0 per 1000 respectively) was not statistically significant $(p=0 \cdot 15)$. Examination of the records did not show anything of note.

Diseases of the oesophagus, stomach, and duodenum (ICD 530-537) and

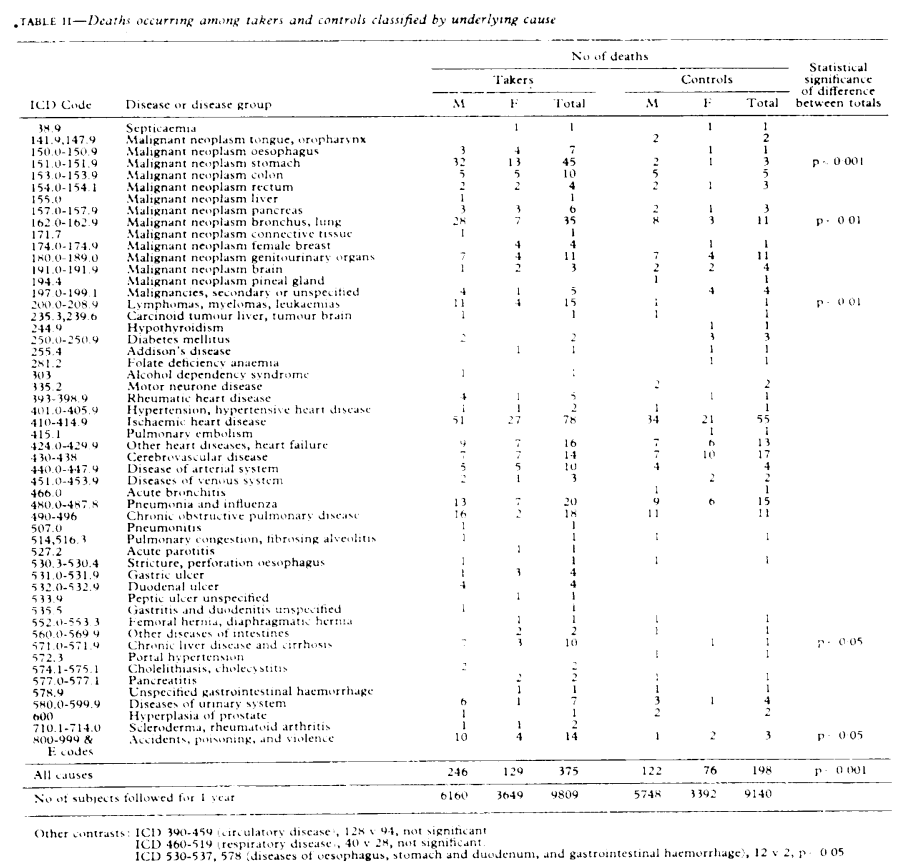

gastrointestinal haemorrhage (ICD 578) (expected mortality in takers 1.2 men, 0.7 women)-Four takers died from a gastric ulcer (haemorrhage in three, perforation in one), four from a duodenal ulcer (haemorrhage in three, perforation in one), one from a perforated oesophageal ulcer, one from gastritis (haemorrhage) (diagnosed at necropsy), one from a peptic ulcer of unknown site, and one from a gastrointestinal haemorrhage probably from an oesophageal ulcer or oesophagitis secondary to a hiatus hernia. Survival varied from one day to 30 months after the first prescription for the drug. Six subjects had not taken cimetidine for at least six months before death. In none of the others was there any evidence that death followed sudden withdrawal of the drug except perhaps for an 82 year old woman who had a fatal haematemesis 24 days after stopping the drug; she was, however, taking indomethacin and other analgesics at the time of death. We have no information about the taker who had a perforated oesophageal ulcer, but we suspect that only four deaths (one in a 90 year old man with multiple pathology, including cancer of the kidney) occurred during treatment with cimetidine.

TABLE III-Details of subjects with lung cancer first diagnosed more than six months after taking cimetidine

\begin{tabular}{|c|c|c|c|c|c|}
\hline $\begin{array}{l}\text { Age } \\
(\operatorname{sex})\end{array}$ & $\begin{array}{c}\text { Indication } \\
\text { for treatment }\end{array}$ & $\begin{array}{l}\text { Time of entry } \\
\text { into study in } \\
\text { relation } \\
\text { to first } \\
\text { prescription }\end{array}$ & $\begin{array}{c}\text { Interval } \\
\text { between } \\
\text { first } \\
\text { prescription } \\
\text { and diagnosis } \\
\text { (months) }\end{array}$ & $\begin{array}{l}\text { Interval } \\
\text { between } \\
\text { diagnosis } \\
\text { and death } \\
\text { (months) }\end{array}$ & $\begin{array}{l}\text { No of tablets } \\
\text { taken before } \\
\text { diagnosis }\end{array}$ \\
\hline $\begin{array}{l}66(\mathrm{~F}) \\
59(\mathrm{M}) \\
45(\mathrm{M}) \\
66(\mathrm{M}) \\
52(\mathrm{~F}) \\
71(\mathrm{~F}) \\
70(\mathrm{M}) \\
50(M)\end{array}$ & $\begin{array}{l}\text { Duodenal ulcer } \\
\text { Gastritis } \\
\text { Peptic ulcer } \\
\text { Duodenal ulcer } \\
\text { Stomal ulcer } \\
\text { Duodenal ulcer } \\
\text { Dyspepsia } \\
\text { Duodenal ulcer } \\
\text { (bleeding) }\end{array}$ & $\begin{array}{l}\text { Same time } \\
\text { Same time } \\
3 \mathrm{~m} \text { later } \\
1 \mathrm{~m} \text { later } \\
\text { Same time } \\
1 \mathrm{~m} \text { later } \\
5 \mathrm{~m} \text { later } \\
1 \mathrm{~m} \text { later }\end{array}$ & $\begin{array}{r}7 \\
7 \\
8 \\
9 \\
10 \\
10 \\
10 \\
11\end{array}$ & $\begin{array}{c}1 \\
3 \\
5 \\
\text { At necropsy } \\
1 \\
1 \\
2 \\
7\end{array}$ & $\begin{array}{r}700 \\
140 \\
60 \\
750 \\
750 \\
60 \\
570 \\
450\end{array}$ \\
\hline $\begin{array}{l}65(M) \\
77(M) \\
67(M)\end{array}$ & $\begin{array}{l}\text { Duodenal ulcer } \\
\text { Haematemesis } \\
\text { Peptic ulcer }\end{array}$ & $\begin{array}{l}12 \mathrm{~m} \text { later } \\
21 \mathrm{~m} \text { later } \\
15 \mathrm{~m} \text { later }\end{array}$ & $\begin{array}{l}19 \\
22 \\
22\end{array}$ & $\begin{array}{l}2 \\
1 \\
1\end{array}$ & $\begin{array}{r}1500 \\
130 \\
>100\end{array}$ \\
\hline
\end{tabular}

Chronic liver disease and cirrhosis (ICD 571) (expected mortality in takers 0.5 men, 0.25 women)-Most of these takers were given cimetidine as part of the management of the terminal stages of cirrhosis of the liver, identified as alcoholic in five and established for many months or years in all. The number of tablets prescribed did not exceed 200 for any taker. In no case was there any suggestion of a causal link between cimetidine treatment and the disease, although we cannot, of course, prove that the drug did not exacerbate an already precarious clinical condition.

Accidents, poisoning, and violence (ICD 800-999, E codes) (expected mortality in takers 3.8 men, 2.0 women $)$-The deaths in takers were the result of: overdose of drugs (not cimetidine) or alcohol, or both, six; drowning, two; road traffic accident, two; unspecified railway accident, one; carbon monoxide poisoning from a fire, one; air embolism, one; and postoperative wound infection, one. Five of the takers who were poisoned or drowned had a history of depression or alcohol and drug abuse, or both, as did the taker killed in the fire. We can be sure only that two of the 14 subjects were taking cimetidine in the weeks before their death.

Other causes of death-The special groups of causes of death detailed above together account for 226 fatalities among the cimetidine takers and 82 among the controls. In aggregate the remaining causes of death accounted for 149 fatalities $(15 \cdot 2$ per 1000) among the takers and $116(12.7$ per 1000) among the controls, a small difference which is not statistically significant.

\section{SMOKING AND DRINKING HABITS}

In total, 503 questionnaires were sent to takers and 504 to controls response rates were $80 \%$ and $76 \%$ respectively. Questions were asked both about present habits and about habits five years previously. We hoped that the responses to questions on the latter might give some indication of the subjects' habits before the onset of the disease leading to cimetidine treatment. Table IV summarises the most important results. Surprisingly, differences between the takers and controls were small, although takers had a slightly higher consumption of alcohol and smoked more cigarettes in the past than did controls. When asked about the occurrence of stress $55 \%$ of takers but only $42 \%$ of controls admitted to experiencing moderate to severe stress in the past. 
TABLE IV-Results of special inquiry about smoking and drinking habits. (The numbers are percentages)

\begin{tabular}{|c|c|c|c|c|}
\hline \multirow[b]{2}{*}{ Habit } & \multicolumn{2}{|c|}{ Takers $(n=402)$} & \multicolumn{2}{|c|}{ Controls $(n=383)$} \\
\hline & $\begin{array}{c}\text { Present } \\
\text { habits }\end{array}$ & $\begin{array}{l}\text { Habits } \\
5 \text { years } \\
\text { previously }\end{array}$ & $\begin{array}{c}\text { Present } \\
\text { habits }\end{array}$ & $\begin{array}{l}\text { Habits } \\
5 \text { years } \\
\text { previously }\end{array}$ \\
\hline \multicolumn{5}{|l|}{ Drinking: } \\
\hline $\begin{array}{l}\geqslant 5 \text { Cups coffee daily } \\
\geqslant 5 \text { Cups tea daily } \\
\geqslant 20 \text { Units* alcohol weekly }\end{array}$ & $\begin{array}{l}11 \cdot 4 \\
50 \cdot 0 \\
13 \cdot 7\end{array}$ & $\begin{array}{l}10 \cdot 0 \\
49 \cdot 3 \\
20 \cdot 9\end{array}$ & $\begin{array}{l}14 \cdot 6 \\
42 \cdot 8 \\
14 \cdot 6\end{array}$ & $\begin{array}{l}12 \cdot 8 \\
45 \cdot 2 \\
18 \cdot 5\end{array}$ \\
\hline \multicolumn{5}{|l|}{ Smoking: } \\
\hline$\geqslant 15$ Cigarettes daily & $28 \cdot 9$ & $45 \cdot 0$ & $27 \cdot 6$ & $38 \cdot 1$ \\
\hline
\end{tabular}

* 1 unit alcohol $=0.28$ litre beer or cider, 1 glass wine, 1 tot spirits.

\section{Discussion}

In recent years several different approaches to the surveillance of newly marketed drugs have been sugested. ${ }^{5-8}$ The approach that we finally adopted was similar to that proposed by Lawson and Henry. ${ }^{7}$ On the whole we were satisfied with the outcome. Our study shows that it is possible to gain the cooperation of large numbers of doctors and pharmacists (including those working in retail practice), to recruit thousands of takers of the drug of interest together with controls, and to record major illnesses and deaths occurring over one year with minimal loss to follow up. We are, of course, aware that studying a sample of 10000 drug takers offers only a modest likelihood that rare adverse reactions will be detected and that the choice of a suitable group for comparison is extremely difficult. These problems are, however, common to the other new approaches to drug surveillance that have been proposed. A more important limitation of our method is its dependence on skilled research assistants for the collection of much of the data. This means that costs are high and that only widely used drugs may be studied since each research assistant can cover only a restricted geographical area. At the same time the use of dedicated personnel ensures that accurate data are collected and that follow up rates are satisfactory.

The data shown in table II are worrying at first glance, but detailed analysis shows that the different drug-disease associations do not, so far as we can tell, represent adverse effects of cimetidine treatment. Instead, in most instances, the associations result from cimetidine being used, knowingly or unknowingly, for treating the symptoms of various diseases-for example, cancer of the oesophagus and of the stomach, malignant lymphoma, peptic ulcer, and cirrhosis-or for alleviating adverse effects of other drug treatments-for example, corticosteroids, non-steroidal anti-inflammatory agents, and radiotherapy.

The large number of excess deaths from lung cancer among the takers could be explained by habitual heavy smoking were it not for the small difference in smoking habits between takers and controls actually recorded by the special questionnaire. Nevertheless, the fact that deaths from pneumonia and chronic obstructive airways disease were also commoner among the takers than the controls suggests that, whatever the responses on the questionnaire, takers were in fact heavier smokers than controls. Having said this, it appears that symptomatic treatment explains most of the association between lung cancer and cimetidine because the drug was given after the diagnosis of lung cancer in 17 cases. In addition, five takers were first found to have lung cancer at the time of diagnosis of peptic ulcer, a direct consequence of intensively investigating such patients.

The difference in mortality from ischaemic heart disease between takers and controls was small and could have been due to chance. In some cases, however, cirhetidine may have been prescribed for cardiac pain in the belief that it was of gastric origin.

We found no evidence, as has been suggested, ${ }^{9}$ that withdrawal of cimetidine is sometimes followed by severe and occasionally fatal relapse of peptic ulcer disease. Instead, in view of the widespread use of cimetidine in gastric emergencies, we were surprised to find so few deaths attributed to peptic ulcer among the takers.

When examining the deaths from accidents and poisonings, we found no evidence that cimetidine induced mental or physical disability, although there were two road accidents and one unspecified railway accident in this group. Generally, cimetidine was apparently often being given for the treatment of diseases related to alcohol or drug abuse, which themselves tend to lead to deaths from violence.

Our special postal survey did not indicate a large difference in smoking or drinking habits between takers and controls, but our method of inquiry was crude (especially as we were most interested in past rather than present habits) and we do not know the habits of those who died. Certainly we have evidence, both from the deaths occurring from chronic liver disease and from those occurring from accidents and poisonings, that heavy drinkers were attracting cimetidine prescriptions and thereby producing non-causal associations in our data.

We conclude $(a)$ that our method of postmarketing surveillance is both feasible and useful; $(b)$ that the interpretation of data obtained from studies such as ours is complex (it would be very easy to jump hastily to the wrong conclusions); and $(c)$ tha we have been unable to find any evidence of fatal adverse effects of cimetidine in a study of nearly 10000 subjects taking the drug. We are analysing our morbidity data and are continuing to identify deaths among takers soon after they occur with the help of the NHS central registries.

We thank Mrs Margaret Edmond, Mr Tom Lucas, Mrs Maureen Rillie, and Mrs Shirley Wood for conducting the field work, Mr John Beresford for help with computing, and Dr Tony Flind for assistance and advice. We also thank the many general practitioners and thei staff, the pharmacists for enthusiastic cooperation, and the Prescription Pricing Bureau for help. The study was supported by a grant from Smith Kline \& French Laboratories Ltd.

\section{References}

1 Schlippert W. Cimetidine $\mathrm{H}_{2}$-receptor blockade in gastrointestinal disease. Arch Intern Med 1978;138:1257-60.

2 Colin-Jones DG, Langman MJS, Lawson DH, Vessey MP. Postmarketing surveillance. In: Baron $\mathrm{JH}$, ed. Cimetidine in the 80 's. Edinburgh: Churchill Livingstone, $1981 ; 270-4$

${ }^{3}$ Colin-Jones DG, Langman MJS, Lawson DH, Vessey MP. Cimetidine use and gastric cancer: a preliminary report from a post-marketing surveillance study. $\mathrm{Br} \mathrm{Med} \mathcal{F} 1982 ; \mathbf{2 8 5}: 1311-3$

4 World Health Organisation. Manual of the international statistical classification of diseases, injuries and causes of death. Geneva: World Health Organisation, 1978

5 Jick H. The discovery of drug induced illness. $N$ Engl f Med 1977;296 $481-5$.

${ }^{6}$ Dollery CT, Rawlins MD. Monitoring adverse reactions to drugs. $\mathrm{Br} \mathrm{Med}$ f 1977 ; : $: 96-7$.

7 Lawson DH, Henry DA. Monitoring adverse reactions to drugs: "restricted release" or "monitored release"? Br Med f 1977;i:691-2.

8 Wilson AB. Post-marketing surveillance of adverse reactions to new medicines. Br Med 7 1977;ii:1001-3.

9 Wallace WA, Orr CME, Bearn AR. Perforation of chronic peptic ulcers after cimetidine. $B r$ Med $\mathcal{F} 1977$;ii :865-6.

(Accepted 3 March 1983)

A patient with scleroderma remembers seeing a programme devoted exclusively to the Spanish vegetable oil scandal on BBC television abou early March 1982. Apparently it was stated that the treatment being given could also be used in the treatment of scleroderma. Is this so?

I saw several patients with scleroderma in Madrid in 1982. Unfortunately, there is no specific treatment to help this aspect of the toxic oil syndrome. Some of the patients were being treated with steroids but it was difficult to assess whether improvement was occurring spontaneously or as a result of this treatment.- I A COTTERILL, consultant dermatologist, Leeds. 